\title{
Fighting Spirits: \\ W. B. Yeats, Ezra Pound, and the Ghosts of The Winding Stair \\ (1929)
}

\section{Lauren Arrington}

IN HIS MEMOIR Bad Boy of Music, the avant-garde composer George Antheil-who met him in Rapallo-describes Yeats as 'a veritable expert on seeing ghosts in broad daylight':

We would often sit together discussing our project [the score for Fighting the Waves], when suddenly he'd say: 'Hello. William', and he'd tip his soft felt sombrero.

I'd follow his look and, seeing nobody within fifty feet of our table, I'd ask him, not without astonishment, where William was.

'Right in the chair alongside of you; he's the ghost of my indigestion', Yeats would say.

Yeats would sometimes talk quite a bit to William, and also other Irish spirits who had been kind enough to come all the way from Dublin to see him. ${ }^{1}$

Yeats's teasing and Antheil's jocularity aside, leaving Ireland was by no means an escape for Yeats from the haunting failures and unresolved resentments that lingered bitterly after the Irish Civil War. Following a successful trip to Sicily in the winter of 1925, where they travelled with Ezra and Dorothy Pound, Yeats and George Yeats planned a trip to Rapallo where Ezra and Dorothy Pound had decided to settle. Yeats's severe illness of autumn 1927 made the journey south all the more necessary. Indeed, the early months of 1928 were a period of physical recuperation as well as creative reinvention. This was the second sustained period that Pound and Yeats lived and worked closely together, and the poems of The Winding Stair, finished at Rapallo in March 1928, reflect the resurrection of their mutual exploration of Noh theatre as well as the importance of the new Italy to Yeats's vision for the emergent Irish state.

Once at Rapallo, in February 1928, and settled into a hotel recommended by the Pounds, Yeats began to attend to the connexions between his physical and mental well-being. The previous autumn, he had read Daisetz Suzuki's Essays in Zen Buddhism: First Series, and that book seems to have inspired his holistic approach. Shortly after his arrival, Yeats wrote to Olivia Shakespear, 'Part of my cure, by the by, is to walk slowly, even turn my head slowly, that my thought from sympathy with my movements may slacken. If it does not I may become my own funeral pyre'.2

Note-Further information may have been gathered since this article was prepared for publication. If you would like to find out if any further information has been discovered that may help your own research, why not write to the author at L.Arrington@liverpool.ac.uk? Apart from anything else, feedback is always welcomed.

${ }^{1}$ George Antheil, Bad Boy of Music (London, New York, etc.: Hurst \& Blackett Ltd., 1947), 171. Antheil continued 'the secret of my success in writing such true Irish music is contained in the fact that Yeats's play is entirely about Irish ghosts. With "William" sitting there alongside of me at the cafe every day, what else could have happened but that William soon became quite visible and even audible, giving me not only most valuable tips on ancient Irish music, but also singing old Irish melodies (in a rather cracked voice, I admit) while I hastily wrote them down in my notebook.' (ibid.).

${ }^{2}$ CL InteLex 5079. At Rapallo, Yeats made a concerted effort to simply his life, to the extent that the furniture ordered for their apartment on the Via Americhe, which they moved into in autumn 1928, was 'without curves and complications', while George painted the furniture 'Chinese red' (Life 2 378-80). 
Yeats believed that his illness was due in part to his bitter state of mind. In 1921, under threat of civil war, he had written to Olivia Shakespear,

I am deep in gloom about Ireland ... I see no hope of escape from bitterness, \& the extreme party may carry the country. When men are very bitter, death \& ruin draw them on as a rabit is supposed to be drawn on by the dancing of the fox (CL InteLex 4039).

In that letter he is referring to what he understood to be the Republican state of mind, but his correspondence from Rapallo reveals that, seven years later, he believed that he had been taken captive by the same bitterness. On 23 February 1928, he wrote to Shakespear,

Once out of Irish bitterness I can find some measure of sweetness, and of light, as befits old age-already new poems are floating through my head, bird songs, of an old mans joy in the passing moment, emotion without the bitterness of memory (CL InteLex 5079).

A letter to Lady Gregory the following day echoes, "This is an indescribably lovely place.... Here I shall put off the bitterness of Irish quarrels, \& write my most amiable verses. ... "The Tower" astonishes me by its bitterness' (CL InteLex 5081).

In April 1928, only recently having arrived in Dublin, he was eager to return:

When I get back to Rapallo I hope to write verse again, but no more bitter passion I think. Re-reading THE TOWER I was astonished at its bitterness, and long to live out of Ireland that I may find some new vintage. Yet that bitterness gave the book its power and it is the best book I have written. Perhaps if I was in better health I should be content to be bitter. ${ }^{3}$

But bitterness was a quality he could ill afford, and The Winding Stair, published by the Fountain Press in 1929, shows Yeats in the process of self-overcoming, exemplified in that volume's 'A Dialogue of Self and Soul'.4 The dialectical logic on which the poem is based-and which characterises $A$ Vision's solar and lunar cycles-was dramatized in Yeats's relationship with Pound. In A Packet for Ezra Pound, first published as a small book by the Cuala Press in 1929 and later placed at the beginning of $A$ Vision (1937), Pound is represented as a mirror, both 'the opposite of all I have attempted' and the reflection; Yeats writes of himself in relation to Pound, 'I too a revolutionist'. 5 The claim is unexpected, upending his familiar positioning of his work in opposition to Pound's and collapsing the distance Yeats attempted to impose between himself and the idea of revolution, in both the Irish and Russian contexts and as an abstract idea. ${ }^{6}$

\footnotetext{
${ }^{3}$ CL InteLex 5104, to Olivia Shakespear, 25 April 1928.

${ }^{4} \mathrm{He}$ later noted in the commentary to the 1933 Macmillan edition, the poem was 'finished the day before a Cannes doctor told me to stop writing', VP 831.

${ }^{5}$ AVB 6; CW14 6; Life 2 381-82.

${ }^{6}$ In another passage in A Packet for Ezra Pound, Yeats implies a similarity between himself and Pound when he advises Pound not to join the Senate of his own country: 'You and I, those impressive and convinced politicians, that young man reciting 'Eugene Aram', are as much out of place as would be the first composers of sea-shanties in an age of steam' (AVB 20; CW14 20). Yeats read Wyndham Lewis's Time and Western Man (London: Chatto \& Windus, 1927; YL 1126) at Cannes before arriving at Rapallo. In Ch 9 of Book 1 (itself entitled 'The Revolutionary Simpleton') Lewis characterizes Pound thus: '... Pound is not a vulgar humbug even in those purely propagandist activities, where, to my mind, he certainly handles humbug, bug quite innocently, I believe. Pound is - that is my belief - a genuine naif. He is a sort of revolutionary simpleton!' (54). The epithet resonated with the way that Yeats was creating a new structure for the relationship of himself to some of his closest acquaintances. See also Time and Western Man, ed. with afterword and notes by Paul Edwards (Santa Rosa: Black Sparrow Press, 1993), 37.
} 
In A Packet for Ezra Pound, Yeats includes a poem 'Meditations Upon Death', which explores the question of oneness, the truth that is achieved through the dialectical process. The poem was not published in A Vision (1937) and was later rewritten as two poems, 'At Algeciras-A Meditation Upon Death' and 'Mohini Chatterjee', which were both included in the 1933 Macmillan edition, The Winding Stair and Other Poems. ${ }^{7}$ Lines from the part of 'Meditations' that became 'Mohini Chatterjee' relay these instructions from 'the Brahmin':

\author{
Pray for nothing, say \\ Every night in bed, \\ 'I have been a king, \\ I have been a slave, \\ Nor is there anything, \\ Fool, rascal, knave, \\ That I have not been'. ${ }^{8}$
}

Yeats's phrase 'I too a revolutionist' illustrates his dismantling of dialectical thought and his trying on of different personae ('fool, rascal, knave'). In Essays in Zen Buddhism: First Series, which was so important to Yeats, Suzuki stresses the insufficiency of dialectical reasoning; he makes it clear that Zen is non-logical: '... Zen mistrusts the intellect, does not rely on traditional and dualistic methods of reasoning, and handles problems after its own original manners'. ${ }^{9}$

Explorations in non-dualistic thought were key to Yeats's attempt to discard 'Irish bitterness' during his convalescence. 'I too a revolutionist' was not only a means of positioning himself in relation to Pound but also relates to Yeats's political thought. In his little book, $W$. $B$. Yeats and Japan, Shotaro Oshima writes, 'He accepted Zen in order to build up a positive philosophy on which he could depend more firmly than on political anti-British thought or enthusiastic patriotism'.1011

Oshima's book has a little hagiography and a lot of proselytizing about it; nonetheless, it identifies crucially the connexion between Yeats's reading in Zen philosophy and his attempts to come to terms with the failures of the Irish revolution. The question of 'revolution'-personal and political-is addressed explicitly in Suzuki's Essays in Zen Buddhism: First Series: 'For what Zen proposes to do is the revolution, and the revaluation as well, of oneself as a spiritual entity.'12 This is a 'complete revolution' that is 'cataclysmic' for the self and for society. Suzuki writes,

\footnotetext{
${ }^{7}$ Harper and Paul note that the annotated copy of A Packet for Ezra Pound sent to Macmillan as setting copy for $A V B$ suggests that Yeats 'may not have initially intended to cut the poem': see CW14 301-2, n.47.

${ }^{8}$ VP 495-96. See also CW14 xxxv.

${ }^{9}$ Diasetz Teitaro Suzuki, Essays in Zen Buddhism: First Series (London: Luzac and Company, 1927), 256, YL 2033.

Hereafter, Suzuki, Essays in Zen Buddhism. Yeats's copy has marginal strokes between 120-44, while line 16

'Enlightenment' of 120 has an annotation in his hand: 'will I Daimon I pure act'.

${ }^{10}$ Shotaro Oshima, W. B. Yeats and Japan (Tokyo: Hokuseido Press, 1965). 1; Yeats inscribed a copy of The Winding Stair to Oshima, including lines from the poem 'Tom O'Roughley': Wisdom is a butterfly I and not a gloomy bird of prey'. In July 1928, Yeats told Thomas Sturge Moore, who designed the frontispiece for The Tower, that he often included these lines from 'Tom O'Roughley' alongside his autograph: 'I remembered when I got back that when I sign a book for anybody I put a line of verse very commonly "For wisdom is a butterfly \& not a gloomy bird of prey." I used to write - in cheerful youth "As to living our servants will do that for us." Can you leave me space on that design for such a line'. The result is reproduced in YA4 180, Fig 1.
}

12 Suzuki, 217. 
The growth of the organism called society is also marked with painful cataclysms, and we are at present witnessing one of its birth-throes. We may calmly reason and say that this is all inevitable, that inasmuch as every reconstruction means the destruction of the old regime, we cannot help going through a painful operation. But this cold intellectual analysis does not alleviate whatever harrowing feelings we have to undergo. The pain heartlessly inflicted on our nerves is ineradicable. Life is, after all arguing, a painful struggle. ${ }^{13}$

The imagining of society as a body like the self, which had to undergo violent periods of destruction in order to reconstruct itself, resonated with Yeats's experience of convalescence at Rapallo, where he remade his 'bitter' Tower images and where he reworked both the personal and historical cycles of remaking in his notes for $A$ Vision (1937). The ideas encountered in Suzuki's Essays in Zen Buddhism: First Series lay the foundations for the far-right ideas articulated in later work such as 'A Race Philosophy' (1933), where Yeats writes about the inadequacy of fascism and communism as political structures because they are based on 'reason' whereas society is 'the struggle of two forces not transparent to reason, the family and the individual.'14

'A Race Philosophy' was written the year before Yeats gave up his apartment in Rapallo, but as early as the first spring that he spent with Pound in Italy, Yeats was connecting Ezra Pound to his own bitterness about Irish politics. For example, in a letter to Lady Gregory on 1 April 1928, Yeats writes,

He has most of Maud Gonnes opinions (political \& economic) about the world in general, being what Lewis calls 'the revolutionary simpleton'. The chief difference is that he hates Palgraves "Golden Treasury" as she does the Free State Government, \& thinks even worse of its editor than she does of President Cosgrave'.15

Like Gonne, Pound was instrumental to Yeats's creativity, and-as in his relationship with Gonne-their friendship was charted according to the constellations of the recent past. Before Yeats married George Hyde-Lees in 1917, he spent three winters living with Pound in Stone Cottage, near Coleman's Hatch in Ashdown Forest, East Sussex. James Longenbach's book on this period aims to show how it was foundational to major turns in both of their work:Stone Cottage was a seedbed for The Cantos and for Yeats's later esoterica, but it was also a breeding ground for some of the unfortunate excesses of [Pound's 1935 treatise] Jefferson and/or Mussolini and On the Boiler. ${ }^{16}$

The dangerous element of their relationship lay in what Longenbach describes as Pound's sense of 'the secret society of modernism'.17

\footnotetext{
${ }^{13}$ Ibid., 3.

14 'A Race Philosophy,' NLI MS 30,280.

${ }^{15}$ CL InteLex 5097. For a discussion of Yeats, Pound, and Palgrave's Golden Treasury, see Warwick Gould, 'The Unknown Masterpiece: Yeats and the Design of the Cantos' in Andrew Gibson ed., Pound in Multiple Perspective (London: Macmillan, 1993), 40-92, 42. On Pound's hatred of Palgrave's Golden Treasury and its consequences 'see Warwick Gould, '”Witch" or "Bitch" - Which? Yeats, Archives, and the Profession of Authorship', in Warwick Gould and Thomas F. Staley (eds.), Writing the Lives of Writers (London: Macmillan Press, 1998), 173-90.

${ }^{16}$ See James Longenbach, Stone Cottage: Pound, Yeats, and Modernism (New York: Oxford University Press, 1988), xi-xii.

${ }_{17}$ Ibid., xii. Longenbach's catchphrase took its origin in his 'The Secret Society of Modernism: Pound, Yeats, Olivia Shakespear, and the Abbé de Montfaucon de Villars', YA4 103-20. But in Stone Cottage, he specifies that it was Pound who 'began to think of Yeats and himself as an artistic and social elite - a secret society - that excluded even some of their closest friends' (ibid., xi). Foster is more sceptical than Longenbach, describing Stone Cottage as a 'quasi-collaboration': see Life 2 380. On Yeats and claims for 'Modernism' in other essays in this volume, see above, pages tbc.
} 
The correlation of Stone Cottage and Rapallo also presents a contrast. At Stone Cottage, Yeats and Pound were secluded from society, but at Rapallo, they were at the centre of a coterie. Pound claimed this group as his own 'Ezuversity', but the letters and memoirs of writers and artists who circulated through the little seaside town reveal that Yeats was often the greater draw. 18

It was not just the busy private sphere of the literati that marks the difference. Rapalloalbeit provincial-sat squarely within Mussolini's regime, a regime with which, in its early years, Yeats seems to have been in agreement as much as Pound. Ezra Pound had imagined, on moving to Italy, that he might be literary advisor to Mussolini. Yeats's relationship to Italian fascism is less direct but nonetheless troubling. In August 1924-the same year that Pound moved from Paris to Rapallo-Yeats quoted Mussolini in his speech at the banquet held in conjunction with the Tailteann Games. He proclaimed, 'as a great popular leader has said to an applauding multitude, "We will trample upon the decomposing body of the Goddess of Liberty"' (Life 2 265). Foster observes that the speech was 'marvellously at odds with the general tone of the evening' (Life 2 266). But is it possible that Yeats interpreted the Games - the Free State's attempt to use mass spectacle for purposes of cultural unification-as being in alignment with the tactics of the new Italy? After all, in November 1922, just a week after Mussolini's March on Rome, Yeats had written to Herbert Grierson, Professor of English Literature at the University of Edinburgh, 'The Ireland that reacts from the present disorder is turning its eyes towards individualist Italy'.19 The adjective is puzzling, especially with reference to a regime that declared at its outset the supremacy of the corporate state over the individual. In the Commentary on a Parnellite at Parnell's Funeral (1935), Yeats describes George Bernard Shaw, Oscar Wilde, and George Moore as 'the most complete individualists in the history of literature, abstract, isolated minds, without a memory or a landscape' (VP 834-35). In the commentary, these three individualists serve as a transitional phase between 'an agrarian political party, that degraded literature with rhetoric and insincerity' and a new phase, marked by the death of Parnell, when 'we began to value truth [....] We had passed through an initiation.' In light of the

\footnotetext{
${ }^{18}$ George Antheil remarks on Yeats's approachability: I had never so much as met a Nobel Prize winner before, and now, every day, I could sit down with two of them [Yeats and Gerhard Hauptmann] and question them on all kinds of little mundane matters, such as what they were feeding their dogs on, had they read any good detective stories lately, etc.' (Antheil, Bad Boy of Music, 180), before telling the story of how Yeats [and, it has been claimed, George Yeats: see BG 416], Hauptmann, Pound, and others helped him to write Death in the Dark, a selfconfessed 'poorly-written but honest to God detective story' published in 1930 as by 'Stacey Bishop' by Faber \& Faber, on a positive report by T. S. Eliot: see Martin Edwards's introduction to the New York, Locked Room International edition (2016), 9. For images of Yeats and Pound at the Café Aurum, Rapallo, see YA7, Plates 2 and 3 , one of which is reproduced in Life 2, Plate 11.

${ }^{19}$ CL InteLex 4020. See also Stanfield 'Free State' in In Context, 58. In the Commentary on A Parnellite at Parnell's Funeral (referring to the poem that was retitled 'Parnell's Funeral' and published in A Full Moon in March [1935]) Yeats writes, 'In the eighties of the last century came a third school: three men too conscious of intellectual power to belong to a party, George Bernard Shaw, Oscar Wilde, George Moore, the most complete individualists in the history of literature, abstract, isolated minds, without a memory or a landscape. It is this very isolation, this defect, as it seems to me, which has given Bernard Shaw an equal welcome in all countries, the greatest fame in his own lifetime any writer has known. Without it, his wit would have waited for acceptance upon studious exposition and commendation' VP 834. The connexion between Ireland and Italy was developed by Yeats's reading in philosophy; he discusses Berkeley's Commonplace Book in Commentary on A Parnellite, and in a letter to Sir Frederick Macmillan, introducing Joseph Hone, Yeats wrote 'He wishes to edit Berkeley's Commonplace Book and translate for it the only adequate commentary. The commentary has been published in Bologna by Mario Rossi [....] The Commonplace Book is of great philosophical importance. Giovanni Gentile begins his chief work with an account of it, finds in it the prophecy of modern idealism; but thinks what Berkeley published during his life-time but a compromise and a falling away'. See Life 2 732, n.147.
} 
development of Yeats's thought, it seems plausible that his praise of 'individualist Italy' signals his belief that contemporary Ireland was undergoing another transitional phase during the establishment of the Free State and that the new Ireland might look for guidance from its southern European counterpart.

In the two years between the Civil War and the Tailteann Games, Yeats's gaze on Italy had hardly slackened. One of the notables invited to speak at the Games was Gabriele d'Annunzio, whom Yeats was clearly intent on hosting-so much so that he wrote to him personally on 2 July, just a month before the Games were held, because d'Annunzio had not replied to the organizing committee's initial invitation. In the letter, Yeats addresses him as 'illustrious poet', but like himself, d'Annunzio was also a playwright, a statesman of sorts, as well as an architect of his country's aesthetics. ${ }^{20}$ In March 1924 (just a few months before Yeats's letter), d'Annunzio had been given the title 'Principe di Montenevoso', awarded in celebration of his short-lived seizure and dictatorship of Fiume in 1919. During the nineteen months that he governed, d'Annunzio had created the components of corporate performance that Mussolini would later adopt, namely, the choreography of the crowd (which D'Annunzio directed through call and response), the use of costume - the black shirt worn by Fiume's Legionnaires, the 'Roman' salute, and the song 'Giovinezza' (or 'Youth'). ${ }^{21}$

Yeats's interest in d'Annunzio can be traced to the first years of the twentieth century, although he makes it clear in his early letters about d'Annunzio's work that he was undecided on its merits. ${ }^{22}$ Just why Yeats was so keen on his presence at the Games is indicated by two points. First, Foster notes that in a draft of the Tailteann speech, Yeats referred to the 'industrial unrest which had nearly sabotaged the opening of the Games'. He quotes the following passage, which was omitted from Yeats's remarks: 'We have exchanged revolver shots for strikes, illegal violence for the legal violence of a small minority that has claimed the right to deprive of the necessities of life and health many thousands' (Life 2 265). Although the passage was unspoken, it suggests significant parallels between the political crisis in Ireland and what Yeats perceived as an Italian solution. The (Italian) National Fascist Party, formed in 1921, had at its inception banned the right to strike, in reaction against the nearly two thousand industrial strikes and nearly two hundred peasant strikes of $1920 .^{23}$

Secondly, while it banned strikes, the Party asserted the supremacy of the state over the liberty of the individual. At the Tailteann Banquet, Yeats cited Mussolini's authoritarianism as a cure for 'nineteenth-century liberalism', and he proposed that the task for future generations would be 'not the widening of liberty, but recovery from its errors: that they will set their hearts upon the building of authority, the restriction of discipline, the discovery of a life sufficiently heroic to live without opium dreams'. ${ }^{24}$ Similarly to 'individualist Italy' the idea of constructive authoritarianism would be developed in the Commentary on A Parnellite at Parnell's Funeral.

\footnotetext{
${ }^{20}$ CL InteLex 4582. Lucy Hughes-Hallett, The Pike: Gabriele D'Annunzio: Poet, Seducer and Preacher of War (London: Fourth Estate, 2013), passim.

${ }^{21}$ Robert Pearce, 'D'Annunzio, Fiume and Fascism', History Review 64 (Sept. 2009), 24.

${ }^{22}$ At this time Yeats's own 'line' on D' Annunzio was uncertain, as he was to reveal in the San Francisco Examiner on 31 January1904, where he admitted he could not " "make out" the [sic] The Dead City'; Yeats wrote, 'at present ... I do not like to say that I do not like D'Annunzio's plays. ... I do see most lovely passages in his work, but it will take me perhaps a long time to understand him as an artist that has influenced the whole of Europe' CL3 269 n.3, also CL InteLex.

${ }^{23}$ For the wave of strikes, socialist protests, and clashes with police, and subsequent attacks on socialists by

Fascist squads, see Christopher Duggan, The Force of Destiny: A History of Italy since 1796 (London: Penguin, 2008), 421-25.

${ }^{24}$ Stanfield, Context 58 and Life 2266.
} 
Recalling the Huguenot artists who designed tapestries for the House of Lords depicting the Battle of the Boyne and the Siege of Derry, Yeats writes,

they celebrated the defeat of their old enemy Louis XIV, and the establishment of a Protestant Ascendancy which was to impose upon Catholic Ireland, an oppression copied in all details from that imposed upon the French Protestants [....] Armed with this new power, they were to modernise the social structure, with great cruelty but effectively, and to establish our political nationality by quarrelling with England over the wool trade, a protestant monopoly (VP 832-33).

The vision of an authoritarian government as a modernising force-in the social, political, and economic realms - strongly reflects Pound's writing from the same period about the United States, especially Jefferson and/or Mussolini: l'idea statale. Fascism as I have seen it, which was published the same year as Yeats's commentary. For example, in that book Pound also looks to the history of his country with France, writing

Jefferson participated in one revolution [....] He tried to educate another [....] While fat Louis was chewing apples at Versailles, Lafayette and Co. kept running down to Tom's [i.e. Jefferson's] lodgings to find out how one ought to behave, and how one should have a French revolution. ${ }^{25}$

He compares Mussolini's plan for a group of advisors, one representing each profession or segment of the workforce, to Jefferson who 'guided the ruling class. A limited number of the public had the franchise.'26

Yeats also invited Pound to speak at the Tailteann banquet, promising that he would be a 'guest of the nation', would see the Games ('probably a great bore'), the annual Horse Show at Ballsbridge ('about the only thing we do really well'), and would 'be present when I crown in the name of the Irish Academy certain books'. He teased, 'You will also probably be invited to certain country houses, and will be generally made much of, and meet everybody who is to be met, and have admirable opportunities for your usual violence and brutality'. ${ }^{27}$ Yeats and George would offer to host no one else at Merrion Square 'in order that [Pound's] temperament may have full sway and exercise' (CL InteLex 4567). Pound did not take them up on the offer.28

Yeats's speech at the Games, which expresses his ambition for the coming generation to 'discover' the 'heroic' life, points to his ongoing efforts, in the words of Michael Valdez Moses, 'to create a ritualistic, heroic, cultic, and anti-democratic form of dramatic tragedy from 1916 onwards' ${ }^{29}$ Essential to this new form was Yeats's interpretation of Japanese Noh theatre, which

\footnotetext{
${ }^{25}$ Ezra Pound, Jefferson and/or Mussolini, 14, https://archive.org/details/JeffersonAndOrMussoliniPound1935

${ }^{26}$ Ibid., 17. Unlike Yeats, Pound did not endorse governance according to heredity; he points out that Adams believed in hereditary government while Jefferson, having no sons, did not; Pound goes on to assert that Adams was the only president to have produced a 'line of descendants who have steadily and without a break felt their responsibility and persistently participated in American government throughout its 160 years' Ibid., 19.

${ }^{27}$ The communicators put Pound at Phase 12, characterized by 'intellectual ugliness' and 'violence', although this was also 'the phase of the hero, of the man who overcomes himself, who spends his life in oscillation between the violent assertion of some commonplace pose, and a dogmatism which means nothing, apart from the circumstance that created it'; see Catherine Paul, 'A Vision of Ezra Pound', in Neil Mann, Matthew Gibson, and Nally eds., A Vision: Explications and Contexts (Clemson: Clemson University Press, 2012), 252-68; 254-55.

${ }^{28}$ Pound may have initially planned to go to Dublin. A letter from Desmond Fitzgerald to Pound states, 'W. B. Y. tells me that you are coming over here for the Tailteann Games and that you habitually have trouble about your passport. I enclose notes which may assist you if any hitch arises about your passport. I am looking forward to seeing you.' Desmond Fitzgerald to Ezra Pound (11 July 1924) in Mary Fitzgerald, 'Pound and Irish Politics', Paideuma, 12. 2 (Fall 1983), 383.

${ }^{29}$ Michael Valdez Moses, 'The Rebirth of Tragedy: Yeats, Nietzsche, the Irish National Theatre, and the AntiModern Cult of Cuchulain', Modernism/modernity, 11. 3 (Sept 2004), 561-79 (562). Focusing wholly on the imperial
} 
was the chief accomplishment of the three winters that he spent with Ezra Pound at Stone Cottage: he returned to Noh tropes and other images drawn from Japanese culture in the poems for The Winding Stair, finished at Rapallo.

At the conclusion of their last winter in Sussex, and just a couple of weeks before the Easter Rising, Yeats had produced his first play for dancers, At the Hawk's Well. The consanguinity of these occurrences underscored the connexion between ancient Japan and modern Ireland in his imagination. The colophon to Certain Noble Plays of Japan makes the link explicit: 'Finished on the twentieth day of July, in the year of the Sinn Fein Rising, Nineteen Hundred and Sixteen'. ${ }^{30}$

The Noh form, like Yeats's reading in Zen Buddhism, was put into the service of his responses to recent events in Irish history, codifying emotions that were too raw and responses that were too personal or too controversial to be addressed head-on. As news of the Rising trickled over to England, with reports of the deaths of Pearse, MacDonagh, and others, Yeats was writing his introduction to Pound and Fenollosa's Certain Noble Plays of Japan. And so, Yeats's history of the Noh theatre invokes these new Irish ghosts:

These plays arose in an age of continual war and became a part of the education of soldiers. These soldiers, whose natures had as much of Walter Pater as of Achilles combined with Buddhist priests and women to elaborate life in a ceremony, the playing of football, the drinking of tea, and all great events of state, becoming a ritual (CNPJ xvii).

His introduction anticipates a sustained confluence of Irish history and Japanese tradition in his writing:

... it pleases me to think that I am working for my own country. Perhaps some day a play in the form I am adapting for European purposes shall awake once more, whether in Gaelic or in English, under the slope of Slieve-na-mon or Croagh Patrick ancient memories; for this form has no need of scenery that runs away with money nor of a theatre-building. ${ }^{31}$ (CNPJ xix)

This anticipates The Dreaming of the Bones (1919), Yeats's play about the Easter Rising, in which Nishikigi - the first of Pound and Fenollosa's translations in Certain Noble Plays of Japan-is combined with the legend of Diarmuid and Dervorgilla and which is set neither at Slieve-na-mon nor Croagh Patrick, but almost exactly at their midpoint, near the tower Thoor Ballylee. 32

(in Moses' words 'colonial') relations between Ireland and Britain, Valdez Moses reads Yeats's dramatic innovations as a 'surprisingly progressive and forward-looking critique', 563; the Italian dimension especially calls the 'progressive' nature of the form's politics into question.

${ }^{30}$ Certain Noble Plays of Japan: From the Manuscripts of Ernest Fenellosa, Chosen and Finished by Ezra Pound, with an Introduction by William Butler Yeats (Churchtown: Dundrum, 1916), [51]. Hereafter CNPJ.

31 The actual theatre building was very much on his mind, as made clear in a letter to his sister Lolly, at Cuala: 'I am writing for news of the Abbey \& shall not go over unless it has been burned or badly damaged. There is nothing to be done but do one's work \& write letters. That 'introduction' [to CNJP] by the by is somewhere in the post on its way to Dundrum' (Life 2 46). For another discussion of the colophon, see Chris Morash, 'Bewildered Romance', Field Day Review (2015), 128-29 (123). Yeats wrote to Olivia Shakespear, 'My sisters books are like an old family magazine. A few hundred people buy them all \& expect a common theme. Only once did I put a book into the series that was not Irish - Ezras Noh plays - \& I had to write a long introduction to anex Japan to Ireland.' (CL InteLex 5836, 9 March [1933]).

32 Longenbach draws parallels between the ghosts in The Dreaming of the Bones and Pound's Three Cantos, and notes Pound's similar adaptation of Nishikigi, which he marries with the story of Tristan and Iseult; see Stone Cottage, etc., 232-33. The Clare setting is implied: the 1917 draft of the play was implicitly set in County Wicklow. For a discussion of the importance of the specificity of place and historical moment, see Morash, 'Bewildered Romance', 128-29. 
The Dreaming of the Bones is a subtle critique of the Easter Rising in that Yeats refuses to follow the classical Noh structure, which dictates that the play ends in harmonious resolution. Nishikigi adheres to the classical form and in its second part has the monk pray to save the souls of the tragic couple, who then appear to him and to the audience in a dream, showing themselves as united in the next world. However, Yeats deprives his characters of this happiness in The Dreaming of the Bones, instead emphasizing the penance they must undergo and putting them into an earth-bound purgatory. ${ }^{33}$ Masaru Sekine summarizes, 'Yeats took the theme from the Noh play, but rejected the Buddhist religious elements, which comes as no surprise, given the date of writing.' 34

What is surprising, perhaps, is that Yeats continued to reject certain Buddhist religious elements, even after his study of Suzuki's Essays in Zen Buddhism: First Series. In Peter Nicholls' essay on Ezra Pound and the Noh, he illustrates how 'the Japanese theatre led to a fundamental redirection of Pound's early poetics,' particularly in relation to the structures of time as Pound creates them in The Cantos. ${ }^{35}$ The poems in The Winding Stair demonstrate that ten years after The Dreaming of the Bones was first performed, the Noh continued to be a means for Yeats to codify his responses to Irish political change. Furthermore, these codes were not solely the provenance of Yeats's drama but are also key to his reinvention of his poetry at Rapallo. To put it most succinctly, if $A$ Vision gave Yeats metaphors for his poetry, then Pound and the Noh gave him metaphors for his politics.

Images from Japanese culture feature strongly in The Winding Stair. In early plans for 'A Dialogue of Self and Soul', Yeats noted, '[?No] only the sword gives truth -'. ${ }^{36}$ Early drafts were titled 'Silk, Sword, \& Tower', and in the published poem, 'My Self' appears with 'The consecrated blade upon my knees'. ${ }^{37}$ This 'Is Sato's ancient blade, still as it was, | Still razor-keen, still like a looking-glass | Unspotted by the centuries' (VP 477). It is the return of the sword from 'My Table' the third movement in 'Meditations in Time of Civil War' (from The Tower), where the sword represents the perfected work of art, made possible by one family's ancient line. In

\footnotetext{
${ }^{33}$ For a close reading of the differences between Nishikigi and The Dreaming of the Bones, see Masaru Sekine, 'Yeats and Japan: The Dreaming of the Bones', Irish University Review 45. 1 (2015), 54-68; 56 and 59; in Leonard Nathan's study, he argues that 'The subject of the play is not the experience of any one of the characters, but the spiritual life of Ireland as a nation', see The Tragic Drama of William Butler Yeats (New York: Columbia, 1965), 210. In Morash's genetic analysis of The Dreaming of the Bones, he notes that the first draft of the play extant, from 1917 (the only draft to differ substantially from the published text), implies that the temporal setting for the play is in the aftermath of 1798. In the 1917 version, after the unfolding of the cloth that opens the action, a character who is later named as 'Mac Dermitt' enters the stage. Morash, drawing from Guy Beiner's work on folk history, notes that the famous McDermott of 1798 is not a hero but a traitor. He proposes that in this way, through the workings of folk memory, Yeats is perhaps attempting to tap into the unconscious mind and to imply questions about 1916 - and its 'hero' Sean McDermott - that could not be expressed directly (Morash, 'Bewildered Romance', 126-27). This reading advances Chapman's note in his edition of the manuscript materials that the line 'terrible temptation' is repeated, in several variations, through early drafts, echoing the marvellous ambiguity of 'a terrible beauty' in 'Easter, 1916'; see W. B. Yeats, 'The Dreaming of the Bones' and 'Calvary': Manuscript Materials, ed. by Wayne K. Chapman (Ithaca and London: Cornell University Press, 2003), xxxi.

${ }^{34}$ Sekine, 'Yeats and Japan,' 59.

${ }^{35}$ Peter Nicholls, 'An Experiment with Time: Ezra Pound and the Japanese Noh,' 2; it should be noted that Nicholls incorrectly gives the title of Yeats and Pound's collaboration as Noh: or Accomplishment, which was solely the work of Pound and Fenollosa.

${ }^{36}$ See NLI 13,590 (3) 1 $1^{\mathrm{r}}$ in W. B. Yeats, The Winding Stair (1929): Manuscript Materials, ed. by David R. Clark (Ithaca and London: Cornell University Press, 1995), 23. Hereafter Clark, The Winding Stair (1929): Manuscript Materials. 37 Ibid., 45 and 55.
} 
Certain Noble Plays of Japan, Yeats had used the Noh as a means of justifying his belief in the 'accomplishment' of an inherited tradition:

'Accomplishment' the word Noh means, and it is their accomplishment and that of a few cultured people who understand the literary and mythological allusions and the ancient lyrics quoted in speech or chorus, their discipline, a part of their breeding. The players themselves, unlike the despised players of the popular theatre, have passed on proudly from father to son an elaborate art, and even now a player will publish his family tree to prove his skill. (CNPJ xi)

The perfected work of art is not only enabled by the family's tradition but also by the family's relationship to the state. In 'A Dialogue of Self and Soul', Sato's sword has been kept 'razor-keen' by

That flowering, silken, old embroidery, torn

From some court-lady's dress and round

The wooden scabbard bound and wound,

Can, tattered, still protect, faded adorn.' (VP 477)

The silken cloth worn by women of the Japanese court can refer to just one garment, a kimono. Here, 'A Dialogue of Self and Soul' clarifies the poem that opens The Winding Stair and addresses one of the most difficult legacies for Yeats of the Rising and 'revolution': the 'Two girls in silk kimonos' of 'In Memory of Eva Gore-Booth and Con Markiewicz'.

In his postscript to a letter to Maud Gonne written just before his illness would make work impossible, Yeats noted, 'I have just finished a poem in memory of Con Marckowicz \& her sister Eva'. His purpose for writing to Gonne was not to discuss the poem but to justify to her his support for the Free State's Public Safety Act, which would give the government extraordinary powers over individual citizens. His defence was mitigated by his interpretation of Balzac:

he knew [...] that we may judge acts, but individuals never [.... The great political service that Balzac did me was that he made authoritative government (government which can, at need, be remorseless (as in his "Catherine Des Medicis") interesting in my eyes — that is what I mean by the "strong line," a line drawn upon the fluctuating chaos of human nature - before I had read him only movements for liberty movements lead by lyrical idealists — seemed to me interesting. ${ }^{38}$

In his notes to The Winding Stair and Other Poems, Yeats was forthcoming about some of the influences on that volume:

I was roused to write Death and Blood and the Moon by the assassination of [Minister for Justice, and architect of the Public Safety Bill] Kevin O'Higgins, the finest intellect in Irish public life, and, I think I may add, to some extent, my friend. (VP 831)

Yeats does not, however, discuss his friendship with the Gore-Booth sisters or his anger over their fates leading up to and after Easter 1916. Drafts of 'In Memory of Eva Gore-Booth and Con Markiewicz' show how Yeats mediated his judgement through the poem's now iconic imagery. In late July 1916, just a week before Roger Casement would be hanged, Yeats wrote to Eva Gore-Booth,

${ }^{38}$ CL InteLex 5035, 3 October [1927]. 
I thank you very much for your most interesting account of Casements purpose [....] Will you permit me to say how much I sorrow over the misfortune that has fallen upon your family? Your sister \& yourself, too beautiful figures among the great trees of Lisadell, are among the dear memories of my youth. ${ }^{39}$

In an early draft of 'In Memory of Eva Gore-Booth and Con Markiewicz', these trees are present:

The summer foliage dissappears

Under the October breath

Contagion of the popular breath' 40

As Yeats's work on the poem progressed, the trees were replaced by a single blossom sheared 'from the summer's wreath'. This has the effect of condensing the landscape into a singular image and of dissociating the sisters from the trees that often signify Ascendancy power, as in Yeats's poems about Gregory and Coole Park. ${ }^{41}$ The connexion between the kimonos of 'In Memory of Eva Gore-Booth and Con Markiewicz' and the cloth in 'A Dialogue of Self and Soul' is intensified if we look to earlier drafts of the latter, in which Yeats experiments with the word blossom:

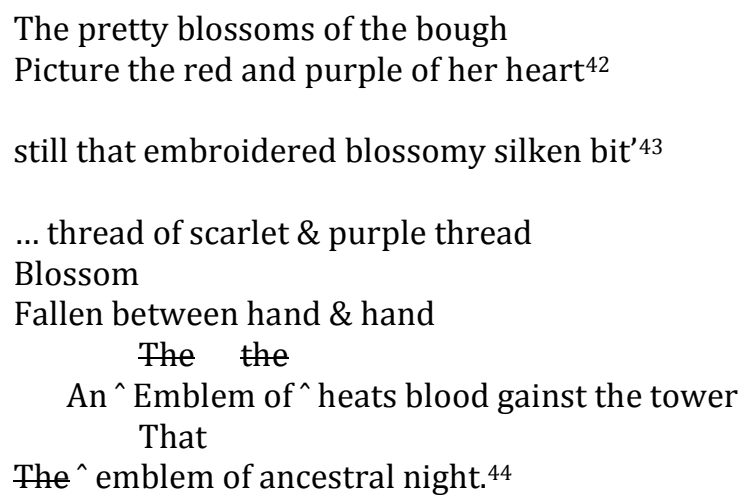

Finally, blossom disappears and becomes 'Flowers from I know not what embroidery' and then 'That flowering, silken, old embroidery [...]'.45

Helen Vendler describes 'In Memory of Eva Gore-Booth and Con Markiewicz' as Yeats's “aristocratic" elegy'. ${ }^{46}$ In his introduction to Certain Noble Plays of Japan, Yeats declared that with what he had learned from the Noh he 'invented a form of drama, distinguished, indirect and symbolic [...] an aristocratic form' (ii). He continues,

The men who created this convention [the Noh] were more like ourselves than were the Greeks and Romans, more like us even than are Shakespeare and Corneille. Their emotion was self-conscious and reminiscent, always associating itself with pictures and poems. They measured all that time had taken or would take away and found their delight in remembering celebrated lovers in the scenery pale passion loves. (CNPJ xv)

\footnotetext{
${ }^{39}$ CL InteLex 3008. Yeats to Eva Gore-Booth (23 July [1916]).

${ }^{40}$ NLI 13,590 (1), 2 ${ }^{\mathrm{r}}$ in Clark, The Winding Stair (1929): Manuscript Materials, 5.

${ }^{41}$ See Anna Pilz and Andrew Tierney, 'Trees, Big House Culture, and the Irish Literary Revival', New Hibernia Review 19.2 (Summer 2015), 65-82.

${ }^{42}$ NLI 13,590(3) 4r in Clark, The Winding Stair (1929): Manuscript Materials, 26-27.

${ }^{43}$ NLI 13,590(3) lv in Clark, Ibid., 28-29.

${ }^{44} \mathrm{NLI} 13,590(3), 5^{\mathrm{r}}$ in Clark, Ibid., 33.

${ }^{45}$ NLI 13,590(3), 6rin Clark, Ibid., 36-37; 48-49; VP 477.

${ }^{46}$ Helen Vendler, Our Secret Discipline: Yeats and Lyric Form (Harvard: Harvard University Press, 2007), 222.
} 
The 'self-conscious and reminiscent' emotion that Yeats believed characterised the Noh is exhibited in 'In Memory of Eva Gore-Booth and Con Markiewicz' where the 'picture' is the poem:

\author{
Many a time I think to seek \\ One or the other out and speak \\ Of that old Georgian mansion, mix \\ Pictures of the mind, recall \\ That table and the talk of youth' (VP 475). ${ }^{47}$
}

The first stanza of the poem takes the sisters out of historical time, renders their ghosts as pure images, and places them in a scene whereby it becomes possible to address them directly-and to extend a measure of forgiveness. ${ }^{48}$

Absolution comes at a price. In 'A Dialogue of Self and Soul', the poet emphasizes twice that he is 'content to live it all again': the process of re-living will bring ultimate blessedness (VP 479). However, the shadows of 'In Memory of Eva Gore-Booth and Con Markiewicz' must undergo a purgation by fire. ${ }^{49}$ In Yeats's notes to The Dreaming of the Bones, he follows his Judwalis in distinguishing between the 'Shade' (or shadow) and the 'Spiritual Being':

The Shade [...] dreams back through events in the order of their intensity, becoming happier as the more painful and, therefore, more intense wear themselves away, and the Spiritual Being' [...] lives back through events in the order of their occurrence, this living back being an exploration of their moral and intellectual origin [....] The Shade is said to fade out at last, but the Spiritual Being does not fade ...50

While the poet anticipates an eternal future as a 'Spiritual Being' in 'A Dialogue of Self and Soul', the Gore-Booth sisters, like the traitorous lovers in The Dreaming of the Bones, are tied to an intermediary state. Indeed, in one draft of 'In Memory of Eva Gore-Booth and Con Markiewicz' the word ghost appears: 'Dear ghosts return \&-strike a match'. 51

As the shadows are transformed, the poem is also changed. The first stanza uses enclosed, or embraced rhyme, containing the image, holding it out of time and framing it in the imagination. ('Lissadell' and 'gazelle' enclose 'south' and 'both'; 'shears' and 'years' enclose 'wreath' and 'death'; 'ignorant' and 'gaunt' enclose 'seek' and 'speak'.) The approximate rhymes of 'recall' and 'gazelle', 'youth' and 'both', at the end of the first stanza, disappoint an

\footnotetext{
47 'In Memory of Eva Gore-Booth and Con Markiewicz' evokes 'Meditations in Time of Civil War', with 'That table' calling to mind 'My Table' on which lies Sato's sword, 'forged' before Chaucer 'had drawn breath' VP 421. ${ }^{48}$ Jahan Ramazani writes, 'Because his elegies can shift turbulently from one response, voice, or discourse to another, Yeats sometimes frames these vacillations with the kind of static picture we find at the first stanza's beginning and end', and he notes that 'The first picture gives an impression of stillness because it excludes all verbs'; see Jahan Ramazani, Yeats and the Poetry of Death : Elegy, Self-elegy, and the Sublime (New Haven: Yale University Press, 1990), 71.

${ }^{49} \mathrm{NLI}$ 13,590(1) $4^{\mathrm{r}}$ lines 38-39 read, 'Some great bellows to a pyre. Some [?greatnobel] bellows to a pire'; Clark 7. ${ }^{50} \mathrm{VPl}$ 777-78. This is reformulated in AVB: 'In the Dreaming Back, the Spirit is compelled to live over and over again the events that had most moved it; there can be nothing new, but the old events stand forth in a light which is dim or bright according to the intensity of the passion that accompanied them. They occur in the order of their intensity or luminosity, the more intense first, and the painful are commonly the more intense, and repeat themselves again and again. In the Return, upon the other hand, the Spirit must live through past events in the order of their occurrence, because it is compelled by the Celestial Body to trace every passionate event to its cause until are all related and understood, turned into knowledge, made a part of itself' (CW14 164). This section, 'The Soul in Judgment' expands significantly $A V A$ 's 'What the Caliph Refused to Learn'.

${ }^{51}$ NLI MS 13,590(1), 4 r in Clark 7.
} 
interpretation of the image as perfect and complete. ${ }^{52}$ The first quatrain of the second movement follows the scheme of the first movement, but then, at a crucial moment - when the spark takes hold-the poem moves into perfect rhyme:

\author{
The innocent and the beautiful \\ Have no enemy but time; \\ Arise and bid me strike a match \\ And strike another till time catch; \\ Should the conflagration climb, \\ Run till all the sages know. \\ We the great gazebo built, \\ They convicted us of guilt; \\ Bid me strike a match and blow. (VP 476)
}

In Certain Noble Plays of Japan, Yeats writes,

my ears are only comfortable when the singer sings as if mere speech had taken fire, when he appears to have passed into song almost imperceptibly. ${ }^{53}$

The carrying over of the enclosed, approximate rhyme-word 'beautiful' into the second movement enables this shift and holds back the pace of the poem until 'match' and 'catch' ignite the metre, letting the last five lines 'climb' and 'run' to their enigmatic conclusion.

Helen Vendler and Roy Foster have both emphasized that an early draft of the poem reads, 'I the great gazebo built | They brought home to me the guilt'.54 The revision is expansive, including the Gore-Booth sisters among the Ascendancy at large, retracting the personal attack, and changing the entire tone of the poem. Vendler comments on Yeats's use of roman numerals in this poem and 'Sailing to Byzantium' as a means of changing location, the speaker's 'station'. ${ }^{55}$ This occurs in the finished poem with the speaker's 'crossing over' into the realm of the dead in the poem's second part. ${ }^{56}$ The change in the poem's directional orientation is also an important part of the revision. Whereas the early draft moves from the exterior 'great gazebo' to the interior 'home', the published version of the poem refrains from turning inward and moves even further out into the metaphysical question of collective guilt, in which the poet acknowledges his share. Jahan Ramazani has written about the ending, 'the coda reass embles a coherent persona and voice. Reconstructed, the poet is now ready to embrace his own fundamental guilt'. ${ }^{57}$ This is borne out in the self-forgiveness of 'A Dialogue of Self and Soul.' 58

\footnotetext{
52 For a thoughtful essay on 'Yeats's Disappointments' see Francis O'Gorman in International Yeats Studies, 1.2 (May 2017), Article 3, http://tigerprints.clemson.edu/iys/vol1/iss2/3

${ }^{53}$ CNPJ iii. Yeats wrote to Poppy Guthrie on 29 April [1932], 'No-no-no I could not write about Plunkett. I might as well sing the mutiplation table [....] Certain necessary \& admirable men remain unsung while pretty women--\& Con Gore-Booth \& her sister Eva were once very pretty - are sung even when neither necessary nor admirable. If I tried to write about Plunkett I would write nothing but rhetoric. A good poem is an accident, begotten <in> through origonal sin' CL InteLex 5658.

${ }^{54}$ Clark, The Winding Stair (1929): Manuscript Materials, 7; Vendler, Our Secret Discipline, 230; Life 2 348-50.

${ }^{55} \mathrm{Ibid} ., 223$.

56 Ibid., 227.

${ }^{57}$ Ramazani, Yeats and the Poetry of Death, 74.

${ }^{58}$ Vendler reads the repetition of the image 'Two girls in silk kimonos' and the echo of 'bid me strike a match' as 'generating a wreath, a circlet'; see Our Secret Discipline, 226. Yeats's hints of circularity gesture to the cycles of rebirth and remaking dealt with in 'A Dialogue of Self and Soul'.
} 
The idea of reconstruction is important to understanding the role that the specific construction of the gazebo plays. It appears in the last stanza, and it is the only time that the word is used in Yeats's poetry or drama. Vendler reads the gazebo as the "folly" of Anglo-Irish culture in an Ireland that was bound to expel their gazebo-architecture in favour of its Catholic and (in Yeats's view) materialistic constructions'. ${ }^{59}$ Gazebos were fashionable ornaments in Georgian gardens, but the structure originated in Asia, and it was brought into the English language by an eighteenth-century book on Chinese architecture. ${ }^{60}$ In its present-day usage, gazebo refers almost exclusively to the building found in outdoor spaces, but its earliest meaning was 'A turret or lantern on the roof of a house, usually for the purpose of commanding an extensive prospect; also, a similar erection in a garden or pleasure ground; a belvedere or look-out'.61 It is a matter of debate whether Yeats's usage embraces this belvedere aspect of the term, which, in twentieth century uses is clearly distinguished from a belvedere or other kind of pavilion, and from lantern, or lookout.

'In Memory of Eva Gore-Booth and Con Markiewicz' provides a bridge between The Tower of 1928 and the new volume that the poem introduces. ${ }^{62}$ In his notes to The Winding Stair (1929), Yeats attributes the image of the tower in 'A Dialogue of Self and Soul' and 'Blood and the Moon' to Thoor Ballylee. However, the Gore-Booth sisters, having rejected the Anglo-Irish tradition, cannot be accommodated in the image of a Norman tower. Nevertheless, Yeats connects them to an ancient lineage, albeit obliquely. The kimono and gazebo allow them to play out their drama in the afterlife as in the Noh theatre, even if the poet can only bear to take them as far as purgation, and, as in The Dreaming of the Bones, he withholds resolution.

While Yeats was writing the poems that would constitute The Winding Stair, Pound was also continuing his study of ancient Asian forms. In the autumn of 1927, he was at work on his rendering "into the American language" of the Ta Hio: the Great Learning, a collection of Confucius's teachings and those of his disciple Tsang Tzu. Pound's biographer A. David Moody summarises, 'it all comes down to seven brief paragraphs which set out, not the abstract principles of good government, but rather the method or process necessary to bring about good government. The development of a certain kind of intelligence is the key.'63 Pound translates the prefatory commentary of the Ta Hio,

The ancient princes who wished to develop and make apparent, in their states, the luminous principle of reason which we receive from the sky, set themselves first to govern well their kingdoms; those who wished to govern their kingdoms well, began by keeping their own families in order; those who wished good order in their families, began by correcting themselves; those who wished to correct themselves tried first to attain rectitude of spirit; those who desired this rectitude of spirit, tried first to make their intentions pure and sincere; those who desired to render their intentions pure and sincere, attempted first to perfect their moral intelligence; the making as perfect as possible, that is, the giving fullest scope to the moral intelligence (or the acquaintance with morals) consists in penetrating and getting to the bottom of the principles (motivations) of actions. ${ }^{64}$

\footnotetext{
${ }^{59}$ Ibid., 229.

${ }^{60}$ The OED cites W. Halfpenny and J. Halfpenny's New Designs Chinese Bridges (1752) as the first usage.

${ }^{61} \mathrm{OED}, n .1$.

${ }^{62}$ In the notes to The Winding Stair and Other Poems, Yeats writes, 'In this book and elsewhere I have used towers, and one tower in particular, as symbols and have compared their winding stairs to the philosophical gyres, but it is hardly necessary to interpret what comes from the main track of thought and expression' VP 831.

${ }^{63}$ A. David Moody, Ezra Pound: Poet-A Portrait of the Man and his Work (Oxford: Oxford University Press, 200715), 2, The Epic Years 1921-1939, 74. Hereafter Moody, Ezra Pound.

${ }^{64}$ Ezra Pound, Ta Hio: the Great Learning (Seattle: University of Washington, 1928), 8 (also available at http://thecantosproject.ed.ac.uk/index.php/canto-xiii/xiii-sources/228-ta-hio-translated-by-ezra-pound-1928). In Pound's Confucius: The Great Digest \& Unwobbling Pivot (New York: New Directions, 1951), Pound replaces
} 
During their seasons at Rapallo, Pound turned to the ever-increasing particularities of good government, and Yeats set out on a course of deeper and deeper spiritual pursuit-a pursuit that found form in his attempt to discern 'the principles (motivations) of [human] actions,' in $A$ Vision (1937). Just as they spent three winters at Stone Cottage with the Noh, Yeats and Pound found common ground at Rapallo through their mutual study of ancient Eastern philosophy and forms. Eastern aesthetics permeate deeply into Yeats's poetry and $A$ Vision, where he describes Rapallo as a place evocative of 'some Chinese painting' (AVB 3; CW14 3). The subtle similarities between Yeats's Commentary on a Parnellite and Pound's Jefferson and/or Mussolini, both published in 1935 at the end of their time together at Rapallo, illustrate the proximity of their politics. Crucially, these politics were articulated not only in Yeats and Pound's visions of the 'new Italy' but also by their interpretation of Zen and Confucian philosophy. Suzuki's Essays in Zen Buddhism: First Series was instrumental to the development of Yeats's right-wing views, since it conceives of the state as a spiritual entity and emphasises the necessity of the cataclysmic destruction of society, ideas also at the core of the Italian fascist regime, which Yeats was observing from abroad through reports of d'Annunzio and Mussolini's activities and, after February 1928, first-hand in Italy. The dangerous confraternity of such unlikely schools of thought is illustrated in Pound's gift to Yeats, in the winter of 1928, of his recently published Ta Hio, which Pound inscribed, 'To Wm. 'Apy noo year 1929 wif' opes of enlightenment EP.'65

\footnotetext{
"princes" with "men of old", eliminates the more mystical overtone of divine wisdom ("receive[d] from the sky") and introduces the verb "disciplined": "The men of old wanting to clarify and diffuse throughout the empire that light which comes from looking straight into the heart and then acting, first set up good government in their own states; wanting good government in their states, they first established order in their own families; wanting order in the home, they first disciplined themselves; desiring self-discipline they rectified their own hearts; and wanting to rectify their hearts, they sought precise verbal definitions of their own inarticulate thoughts; wishing to attain precise verbal definitions, they set to extend their knowledge to the utmost. This completion of knowledge is rooted in sorting things into organic categories" quoted in Moody, Ezra Pound, 2, 75. ${ }^{65}$ YL 1633.
} 